Described from two male specimens, one darker than the other, and differing also in the number of joints of the antennæ, but in no other particulars. C. scutellata is very similar in form and structure, but the antennæ are only tenjointed, not cyathiform, and the three terminal joints are much less distinctly separated than in $C$. cyathiformis.

XII.-Notes on the Genus Entomogramma as represented by the Noctuid Moths of that Group in the Collection of the British Museum. By Arthur G. Butler, F.L.S., F.Z.S., \&c.

When he founded the genus Entomogramma, M. Guenée separated the species under distinct groups in consequence of their different antennal structure; indeed, no two species of the genus as originally constituted are quite alike in their male characters, and one of them was considered by Mr. Moore to be so dissimilar that he made it the type of a new genus. The latter, however, has no higher claim than the others to be so distinguished; and as it would be necessary for the sake of consistency to found a separate genus for every species of the original group, provided that the secondary sexual characters were taken into account, it seems preferable to regard them, as Guenée did, merely as sections of one variable genus.

The practical common sense of this mode of procedure being adinitted, Mr. Hampson has called my attention to the fact that various other species, differing only from typical Entomogramma (in the variability of the same organs in the male sex) in a similar though somewhat different manner, have been wrongly described in the genera Thermesia, Phurys, \&c. By adding these to Entomogramma I find that a tolerably gradational series is formed, evidently related throughout. The species of Entomogramma in the Museum series thus resolve themselves into eight sections, each of which differs somewhat from all the others in its male structure, whilst that of the female remains almost the same, excepting in the case of section $g$, where the female is the modified sex. These sections will now stand as follows :-

\title{
Entomogramma, Guen.
}

Section $a$. Taramina, Moore.

Males with basal third of antennæ dilated, outer two thirds 
pectinated, inner two thirds with short fine deflexed ciliations ; basal area of primaries and basi-internal area of secondaries below densely clothed with hair; femora and tibiæ also densely hairy.

\section{Entomogramma torsa.}

Entomogramma torsa, Guenée, Noct. iii. p. 204. n. 1605 (1852).

Java, Ceylon, Nilgiris, N. India. Type in Coll. B. M.

\section{Section $b$.}

Antennæ dilated as in Section $a$, but biseriate-denticulated and fasciculated; under surface of wings much less hairy; legs quite different, the anterior pair emitting a large fanshaped pencil of hair at the origin of the femur, the latter with a short fringe below, the tibia thickly covered at the back with appressed hairy tufts; remaining legs not hairy, the middle tibiæ coarsely scaled in front and spiny, the posterior tibiæ spiny.

\section{Entomogramma pardus.}

Entomogramma pardus, Guenée, Noct. iii. p. 205. n. 1606 (1852).

Hypopyra anteponens, Walker, Lep. Het. xiv. p. 1323 . n. 2 (1857).

Remigia venusta, Walker, l. c. Suppl. iii. p. 1011 (1865).

S. Africa, Natal, Delagoa Bay, Sierra Leone. B. M.

\section{Section $c$.}

Antennæ very slightly dilated towards the base, with coarse biseriate ciliations, hardly amounting to denticulation; the legs rather more spiny than in Section $b$.

\section{Entomogramma mediocris.}

Entomogramma mediocris, Walker, Lep. Het. Suppl. iii. p. 949 (1865). Remigia decora, Walker, l. c. p. 1015 (1865).

Remigia antica, Walker, l. c. p. 1016 (1865).

South India. Types in Coll. B. M.

Section $d$.

Antennæ regularly ciliated in the male, front and hind legs densely hairy.

\section{Entomogramma fautrix.}

Entomogramma fautrix, Guenée, Noct. iii. p. 204. n. 1604 (1852).

Silhet, Sikkim, Mussoorie, Kangra, Khasia Hills, Nilgiris, Andamans. Type in Coll. B. M. 


\section{Section $e$.}

Antennæ? The female with all the tibiæ fringed externally; second joint of palpi elongated, thickly fringed with dense scales at the back.

\section{Entomogramma subcostalis.}

Thermesia subcostalis, Walker, Lep. Het. Suppl. iii. p. 1059 (1865).

Moulmein. Type in Coll. B. M.

\section{Entomogramma ussuriensis.}

Remigia ussuriensis, Bremer, Bull. Acad. Sci. St. Pétersb. iii, p. 587.

Japan. In Coll. B. M.

\section{Section $f$.}

Second joint of palpi arched at the back, but not densely fringed as in Section $e$. Antennæ of male with short delicate ciliations; legs almost naked, the front and middle tibiæ alone being partly fringed with hair externally.

\section{Entomogramma nigriceps.}

ㅇ. Renodes nigriceps (as o $^{*}$ ), Walker, Lep. Het. xv. p. 1595. n. 6 (1858).

o. Herminia? nigrifrontalis (as 우), Walker, l. c. xvi. p. 258 (1858).

Aden, Abyssinia, Sierra Leone, Natal, South Africa. Types in Coll. B. M.

\section{Var. pallidula.}

Renodes pallidula, Butler, Ann. \& Mag. Nat. Hist. 1875, vol. xvi. p. 409. n. 91.

Natal. Type in Coll. B. M.

\section{Entomogramma melanocephala.}

Poaphila melanocephala, Hampson, Ill. Typ. Lep. Het. viii. p. 82, pl. cxlvi. fig. 9 (1891).

Var. Poaphila marmorea, Hampson, l. c. fig. 7 (1891).

Nilgiris. Types in Coll. B. M.

\section{Entomogramma fuscescens.}

Thermesia fuscescens, Walker, Lep. Het. Suppl. iii. p. 1054 (1865).

Thermesia obumbrata, Walker, $l$. $c$.

Thermesia morosa, Walker, l. c. p. 1055 (1865).

Scambina? larvata, Walker, l. c. p. 1119 (1865).

Natal (Gueinzius). Types in Coll. B. M. 


\section{Entomogramma enervis.}

Phurys enervis, Swinhoe, Trans. Ent. Soc. 1890, p. 231. n. 352, pl. viii. fig. 8.

Rangoon. Type in Coll. B. M.

Section $g$.

Female with the second joint of the palpi broadly fringed both in front and at the back with compressed hair-scales, giving it a wedge-shaped form.

\section{Entomogramma obliqua.}

Phurys obliqua, Moore, P. Z. S. 1867, p. 80.

Burma and Sikkim. In Coll. B. M.

Section $h$.

Second joint of palpi in male broadly fringed and compressed.

\section{Entomogramma oblita.}

Thermesia oblita, Moore, Descr. Ind. Lep. Atk. ii. p. 176 (1882).

Khasia Hills and Chinn Hills. In Coll. B. M.

Mr. Hampson also refers the Thermesia rivulosa of Walker to Entomogramma; but I think it differs so considerably as hardly to warrant its being considered a section of this genus. Both sexes have the third joint of the palpi extremely short, much more so even than in E. pardus; the legs are rather more hairy than in Sections $f$ and $g$; the antennæ of the male are densely but finely fringed on the inside with short ciliations, and at regular intervals emit single longer hairs on both sides; the secondaries of this sex also have the abdominal border expanded and broadly fringed with long hair towards the base. The button-like third joint of the palpi in both sexes redeems this genus from the charge of being based solely on secondary sexual characters, and therefore I propose to call it Blasticorhinus. 


\section{$2 \mathrm{BHL}$ Biodiversity Heritage Library}

Butler, Arthur G. 1893. "XII.-Notes on the genus Entomogramma as represented by the noctuid moths of that group in the collection of the British Museum." The Annals and magazine of natural history; zoology, botany, and geology 12, 43-46. https://doi.org/10.1080/00222939308677575.

View This Item Online: https://www.biodiversitylibrary.org/item/78509

DOI: https://doi.org/10.1080/00222939308677575

Permalink: https://www.biodiversitylibrary.org/partpdf/62260

\section{Holding Institution}

University of Toronto - Gerstein Science Information Centre

\section{Sponsored by}

University of Toronto

\section{Copyright \& Reuse}

Copyright Status: NOT_IN_COPYRIGHT

This document was created from content at the Biodiversity Heritage Library, the world's largest open access digital library for biodiversity literature and archives. Visit BHL at https://www.biodiversitylibrary.org. 